Weed Science

www.cambridge.org/wsc

\section{Research Article}

Cite this article: Dimaano NG, Tominaga T, Iwakami S (2022) Thiobencarb resistance mechanism is distinct from CYP81A-based cross-resistance in late watergrass (Echinochloa phyllopogon). Weed Sci. 70: 160-166. doi: $10.1017 /$ wsc. 2022.4

Received: 9 September 2021

Revised: 21 December 2021

Accepted: 9 January 2022

First published online: 20 January 2022

\section{Associate Editor:}

Vipan Kumar, Kansas State University

\section{Keywords:}

Cytochrome P450; metabolism-based herbicide resistance; non-target site resistance; segregation

\section{Author for correspondence:}

Satoshi Iwakami, Graduate School of Agriculture, Kyoto University, KitashirakawaOiwake-cho, Sakyo-ku, Kyoto 606-8502, Japan. Email: iwakami.satoshi.2v@kyoto-u.ac.jp

\title{
Thiobencarb resistance mechanism is distinct from CYP81A-based cross-resistance in late watergrass (Echinochloa phyllopogon)
}

\section{Niña Gracel Dimaano ${ }^{1}$ (1), Tohru Tominaga ${ }^{2}$ (1) and Satoshi Iwakami ${ }^{3}$ (1)}

${ }^{1}$ Assistant Professor, College of Agriculture and Food Science, University of the Philippines Los Baños, Los Baños, Laguna, Philippines; ${ }^{2}$ Professor, Graduate School of Agriculture, Kyoto University, Kitashirakawa-Oiwake-cho, Sakyo-ku, Kyoto, Japan and ${ }^{3}$ Assistant Professor, Graduate School of Agriculture, Kyoto University, Kitashirakawa-Oiwake-cho, Sakyo-ku, Kyoto, Japan

\begin{abstract}
The genetic and molecular basis of resistance evolution in weeds to multiple herbicides remains unclear despite being a great threat to agriculture. A population of late watergrass [Echinochloa phyllopogon (Stapf.) Koso-Pol.] was reported to exhibit resistance to $\geq 15$ herbicides from six sites of action, including thiobencarb (TB). While previous studies disclosed that the resistance to a majority of herbicides such as acetolactate synthase (ALS) and acetyl-CoA carboxylase inhibitors is caused by the overexpression of herbicide-metabolizing cytochrome P450s (CYP81A12 and CYP81A21), the resistance mechanisms to some herbicides remain unknown. Here, we analyzed the resistance segregation in the progenies between resistant and sensitive populations and performed a transgenic plant sensitivity assay to resolve whether TB resistance is endowed by the same CYP81A12/21-based cross-resistance mechanism or other unknown multiple-resistance mechanisms. In the $\mathrm{F}_{6}$ progenies, resistance to the ALS inhibitor bensulfuron-methyl cosegregated with the resistances to many other herbicides under the CYP81A12/21-based cross-resistance mechanism; however, TB resistance segregated independently. Furthermore, CYP81A12/21 failed to confer TB resistance in transgenic Arabidopsis thaliana L. Heynh, thus confirming that TB resistance in resistant $E$. phyllopogon is not endowed by the two P450s that are responsible for the metabolism-based cross-resistance. This study provides evidence that resistance in E. phyllopogon to herbicides with multiple sites of action is endowed by both P450-based and other uncharacterized non-target site based mechanisms. Our findings add another layer in the understanding of resistance evolution to multiple herbicides in E. phyllopogon. Identification of the key genes endowing TB resistance will be the future direction of this research.
\end{abstract}

\section{Introduction}

Herbicide resistance is the inherited ability of weed biotypes to survive and reproduce following herbicide treatment that is normally lethal to the wild type. Resistance is an outcome of the adaptive evolution of weed populations to the intense selection pressure exerted by herbicide applications (Jasieniuk et al. 1996; Powles and Yu 2010). Two types of mechanisms are involved in herbicide resistance: target-site resistance (TSR) and non-target site resistance (NTSR) (Délye 2013; Powles and Yu 2010; Yuan et al. 2007). TSR is caused by structural alterations or increased activity of the herbicide target protein, while NTSR involves all the other mechanisms of resistance (Délye 2013). NTSR can be attributed to reduced herbicide uptake or translocation or enhanced metabolism of the herbicide (Délye et al. 2015; Yu and Powles 2014). The herbicide resistance observed in weeds can be caused by the expression of one or a combination of the abovementioned mechanisms.

A great concern nowadays is the increasing number of weed populations/individuals that are resistant to herbicides with multiple mechanisms of action (MOAs). The underlying mechanisms of resistance to herbicides with multiple MOAs are classified into (1) accumulations of distinct resistance mechanisms, that is, multiple resistance; and (2) a single mechanism, that is, cross-resistance (Hall et al. 1994). Multiple-resistance cases are often caused by the sequential acquisition of altered herbicide target sites, which are often reflected by the alternative herbicide applications to the populations that had acquired resistance to particular herbicides. The typical examples are accumulations of TSR mechanisms, namely, TSR-based multiple resistance, as reported in diverse weed species worldwide, e.g., acetolactate synthase (ALS) and acetyl-CoA carboxylase (ACCase) substitutions in Japanese foxtail (Alopecurus japonicus Steud.) (Feng et al. 2016) and barnyardgrass [Echinochloa crus-galli (L.) P. Beauv.] (Fang et al. 2019, 2020), and an ALS substitution and a protoporphyrinogen oxidase deletion in waterhemp [Amaranthus tuberculatus (Moq.) Sauer] (Shergill et al. 2018). On the other hand, 
cross-resistance to multiple herbicide MOAs can only be expressed via an NTSR mechanism, namely, NTSR-based cross-resistance. This often refers to enhanced herbicide metabolism based on the observations that weeds, especially in Poaceae with metabolism-based resistance to one herbicide, often extend the resistance to several chemically dissimilar herbicides with diverse MOAs, though the underlying mechanisms mostly remain unknown (Yu and Powles 2014). Phenotypically, it is difficult to characterize whether cross-resistance is conferred by a single metabolic mechanism or whether other multiple distinct metabolic mechanisms are present (Gaines et al. 2020); thus molecular and genetic studies are necessary to identify the underlying resistance mechanisms.

The mystery of extending resistance even to herbicides that are not used in the field is one of the major issues to be solved in herbicide-resistance research. Recent molecular works on the noxious weeds late watergrass [Echinochloa phyllopogon (Stapf) Koso-Pol.] and rigid ryegrass (Lolium rigidum Gaudin) with resistance to five or more MOAs disclosed that grass weeds carry enzymes that metabolize a large number of herbicides, whose activation can result in the evolution of metabolism-based cross-resistance (Dimaano et al. 2020; Han et al. 2021). However, it is still not well understood whether resistance to multiple MOAs via enhanced metabolism is solely endowed by a single NTSR mechanism (cross-resistance) or multiple NTSR mechanisms (multiple resistance). A proper understanding of the extended range of resistance conferred by a single mechanism will provide insight into the limits of cross-resistance, a fundamental for the control of resistant weeds.

In the late 1990s, a resistant (R) population of E. phyllopogon (syn.: Echinochloa oryzicola Vasing.) to multiple herbicides was reported in Sacramento Valley, CA (Fischer et al. 2000). Echinochloa phyllopogon is a predominantly self-pollinated allotetraploid $(2 n=4 x=36)$ grass under the Panicoideae subfamily (Yamasue 2001). If not controlled, this noxious weed can cause approximately $50 \%$ yield reduction, as observed in California water-seeded rice (Oryza sativa L.)-cropping systems (Hill et al. 1985). Reports of resistance in the $\mathrm{R}$ line encompass inhibitors of ALS, ACCase, 1-deoxy-D-xylulose 5-phosphate synthase (DXPS), very-long-chain fatty-acid elongase (VLCFAE), and 4hydroxyphenylpyruvate dioxygenase, and synthetic auxin herbicides (Dimaano et al. 2020; Fischer et al. 2000; Iwakami et al. 2014, 2019; Osuna et al. 2002; Ruiz-Santaella et al. 2006; Yasuor et al. 2009, 2010, 2012). The genetic segregation pattern and molecular mechanism of resistance in R E. phyllopogon to ALS inhibitors (bensulfuron-methyl and penoxsulam), ACCase inhibitors (diclofop-methyl, tralkoxydim, and pinoxaden), and a DXPS inhibitor (clomazone) were previously elucidated (Guo et al. 2019; Iwakami et al. 2014, 2019). Segregation analysis in the $F_{2}$ progenies from a cross between $\mathrm{R}$ and sensitive (S) lines showed that the resistances to these herbicides are under the control of a single locus. In the $\mathrm{F}_{6}$ progenies, the segregation patterns of resistance are perfectly associated in all these herbicides. Moreover, it was revealed that the resistance to these herbicides is due to a single NTSR cross-resistance mechanism, specifically enhanced herbicide metabolism by two cytochrome P450s, CYP81A12 and CYP81A21 (Guo et al. 2019; Iwakami et al. 2014, 2019).

The mechanism(s) of resistance in the $\mathrm{R}$ line to other herbicides, among which is the VLCFAE inhibitor thiobencarb (TB), remain unknown. TB is a thiocarbamate herbicide that potently inhibits shoot elongation of germinated seeds due to the inhibition of VLCFAEs (Roberts et al. 1998; Tanetani et al. 2013). It was first introduced to control Echinochloa spp. in the rice fields in California in the late 1980s (Hill et al. 1985). Roughly $10 \mathrm{yr}$ after its introduction, resistance to TB as well as a few other herbicides was reported, confirming complaints by farmers that the herbicides were no longer effective (Fischer et al. 2000).

Previous evaluation on transformed Arabidopsis thaliana L. Heynh hinted that CYP81A12 and CYP81A21 are not involved in TB resistance (Dimaano et al. 2020). This study was conducted to confirm whether CYP81A12 and CYP81A21, which confer the concomitant NTSR-based cross-resistance to at least four MOAs, could also explain the resistance to TB. By performing trait segregation and transgenic plant sensitivity analysis, we hypothesized that if TB resistance is endowed by CYP81A12 and CYP81A21, then the resistance to multiple MOAs in R E. phyllopogon is solely explained by a single NTSR mechanism. Otherwise, another unknown mechanism is endowing multiple resistance in $\mathrm{R}$ E. phyllopogon. Results of this study will help resolve whether the resistance evolution in E. phyllopogon to diverse herbicide MOAs is instigated by a single NTSR mechanism (cross-resistance) or multiple NTSR mechanisms (multiple resistance).

\section{Materials and Methods}

\section{Origin of Plant Materials and Preparation}

The resistant (R) line, 511 and susceptible (S) line, 401 of E. phyllopogon were originally collected from the rice fields of Sacramento Valley, California in 1997 and were crossed by Tsuji et al. (2003) to produce the $\mathrm{F}_{1}$ population, then self-pollinated for five successive generations to produce $F_{6}$ seeds by single seed descent method (Iwakami et al. 2014; Tsuji et al. 2003). Sterilization was done by washing the seeds with $70 \%(\mathrm{v} / \mathrm{v})$ ethanol for $60 \mathrm{~s}$; then with $2.5 \%$ (active chlorine) sodium hypochlorite solution containing $0.1 \%$ (v/v) Tween 20 (Wako, Osaka, Japan) for $15 \mathrm{~min}$. Seeds were further sterilized for $30 \mathrm{~min}$ with $0.25 \%$ (active chlorine) sodium hypochlorite solution; then washed three times with sterile water.

\section{Dose-Response Assays of Parental Lines}

Dose-response assays of the parental S and R lines of E. phyllopogon were performed in the greenhouse and laboratory facilities of Kyoto University, Japan, during the summer (July to September) of 2019. Each experiment was conducted twice, and each herbicide treatment was replicated three times.

For the greenhouse experiments, sterilized seeds of $\mathrm{S}$ and $\mathrm{R}$ lines were pre-germinated for $3 \mathrm{~d}$ in an incubator set at constant $30 \mathrm{C}$ and constant light (approximately $40 \mu \mathrm{mol} \mathrm{m}^{-2} \mathrm{~s}^{-1}$ ), then 10 pregerminated seeds were sown at a depth of $1 \mathrm{~cm}$ into each plastic pot $\left(0.01 \mathrm{~m}^{2}\right)$ containing $0.8 \mathrm{~kg}$ of autoclaved ( $120 \mathrm{C}$ for $\left.20 \mathrm{~min}\right)$ sandy loam soil with 8-8-8 fertilizer added (after soil was autoclaved). Two days after sowing, TB (Saturn Emulsion, Kumiai Chemical Industry, Tokyo, Japan) was applied to each pot using a hand sprayer at the rates of $0,0.09,0.28,0.83,2.5,7.5,22.5$, and 67.5 $\mathrm{kg}$ ai ha ${ }^{-1}$. After $10 \mathrm{~d}$, the responses of $\mathrm{S}$ and $\mathrm{R}$ lines were visually assessed, and the aboveground biomass was harvested. Fresh weights were measured and expressed as a percentage of the mean of untreated plants. The dose by which growth is reduced by $50 \%$ $\left(\mathrm{GR}_{50}\right)$ was estimated by log-logistic regression with the DRC package (Ritz et al. 2015) in R v. 3.4.4 (R Core Team 2018). The resistance index (RI) was computed as $\mathrm{GR}_{50}$ of the R line over $\mathrm{GR}_{50}$ of the $\mathrm{S}$ line. 
For the laboratory experiments, three sterilized seeds each of the parental $\mathrm{S}$ and $\mathrm{R}$ lines were grown in glass tubes $(130 \mathrm{~mm}$ by $40 \mathrm{~mm}$ ) containing $30 \mathrm{ml}$ Murashige and Skoog (MS) solid media mixed with different concentrations $(0,0.1,1,10,30$, and $100 \mu \mathrm{M}$ ) of TB (Fujifilm Wako Chemicals, Miyazaki, Japan). The seedlings were grown at $28 \pm 5 \mathrm{C}, 15$-h photoperiod, and approximately $70 \mu \mathrm{mol} \mathrm{m}^{-2} \mathrm{~s}^{-1}$ light intensity. After $10 \mathrm{~d}$, the sensitivities of $\mathrm{S}$ and $\mathrm{R}$ lines were visually assessed. Using ImageJ software (Rasband 1997), the height of each seedling was measured from the basal part of the seedling up to the tip of the shoot and expressed in centimeters. All data were expressed as a percentage of the mean of untreated plants. The $\mathrm{GR}_{50}$ dose was determined as described earlier, and the RI for each herbicide was computed as $\mathrm{GR}_{50}$ of the $\mathrm{R}$ line over $\mathrm{GR}_{50}$ of the $\mathrm{S}$ line.

\section{Inheritance of Thiobencarb Resistance in $\mathrm{F}_{6}$ Progenies}

Laboratory experiments were performed to determine the cosegregation of TB resistance with bensulfuron-methyl (BSM) resistance in the $\mathrm{F}_{6}$ progenies from crosses between $\mathrm{S}$ and $\mathrm{R}$ E. phyllopogon. The $\mathrm{F}_{6}$ lines used in the experiments were the lines whose sensitivities to BSM and penoxsulam, ACCase inhibitors (diclofop-methyl, tralkoxydim, and pinoxaden), and DXPS inhibitor (clomazone) were perfectly cosegregated and whose gene expressions of CYP81A12 and CYP81A21 were previously assessed (Guo et al. 2019; Iwakami et al. 2014, 2019).

Sensitivity tests were performed as described earlier. Four sterilized seeds of each parental and $\mathrm{F}_{6}$ line were grown on MS solid media mixed with $1 \mu \mathrm{M}$ TB or $10 \mu \mathrm{M}$ BSM, the optimized concentrations that can suppress the growth of the parental S line. The experiments were replicated and conducted only twice due to the limited number of available seeds per each $\mathrm{F}_{6}$ line. The seedlings were then grown following the same procedures described earlier. After $10 \mathrm{~d}$, the responses of each line to $\mathrm{TB}$ and BSM were visually assessed and compared. The height of each seedling was measured from the basal part of the seedling up to the tip of the shoot using ImageJ. The $\mathrm{F}_{6}$ progenies were classified phenotypically as (1) resistant, when the seedlings were healthy and had tolerance similar to the parental $\mathrm{R}$ line; (2) intermediate, when the seedlings had the average growth and sensitivity of the parental S and R lines; (3) segregating, when some seedlings showed tolerance similar to the parental $\mathrm{R}$ line, susceptibility similar to the parental $\mathrm{S}$ line, and intermediate response; and (4) susceptible, when the seedlings had susceptibility similar to the parental S line.

\section{Herbicide Sensitivity of Transgenic Arabidopsis thaliana Expressing CYP81A12/21 Genes}

Homozygous T4 transgenic lines of $A$. thaliana plants, with a single-copy gene and highest expression of CYP81A12 and CYP81A21 under the Cauliflower mosaic virus $35 \mathrm{~S}$ promoter generated in our previous study (Iwakami et al. 2014), were used in this experiment. Herbicide sensitivities of the wild-type (WT; Colombia-0) and transgenic $A$. thaliana plants were assessed by growth on petri plates $(90 \mathrm{~mm}$ by $20 \mathrm{~mm})$ containing MS solid media $(30 \mathrm{ml})$ mixed with the varying concentrations of $\mathrm{TB}(0,3,10,30$, and $100 \mu \mathrm{M})$ or BSM $(0,1,10,100$, and $1000 \mathrm{nM})$. Each experiment was conducted twice in three replications. Each MS medium was divided into three equal portions for the two transgenic $A$. thaliana lines and the WT. Nine seeds of each line were placed in each portion. The MS media were placed in a $4 \mathrm{C}$ refrigerator for $3 \mathrm{~d}$, then transferred to an incubator set at $22 \mathrm{C}$ and $70 \mu \mathrm{E}$ $\mathrm{m}^{-2} \mathrm{~s}^{-1}$ light intensity. At $12 \mathrm{~d}$ after treatment, the growth and sensitivity of transgenic $A$. thaliana plants in all concentrations of TB and BSM were assessed and compared with the WT. The maximum distance $(\mathrm{mm})$ between two points on the A. thaliana rosette boundary, referred to hereafter as "rosette diameter," was measured using ImageJ. Tukey's honest significant difference tests (5\% significance level) were performed to analyze variances among the mean rosette diameter of WT and transgenic lines per each herbicide concentration using Statistical Tool for Agricultural Research v. 2.0.1 (International Rice Research Institute, Los Baños, Philippines).

\section{Results and Discussion}

\section{Thiobencarb Resistance in Parental Lines}

In this study, TB resistance was confirmed in the $\mathrm{R}$ line of E. phyllopogon collected from California. Results of the greenhouse experiment using the commercial formulation of $\mathrm{TB}$ showed a noticeable difference in TB sensitivity between the $\mathrm{R}$ and $\mathrm{S}$ lines (Figure 1A and B). Ten days after herbicide application, the $\mathrm{S}$ line exhibited severe symptoms, such as stunting of growth and leaf chlorosis, even at $2.5 \mathrm{~kg}$ ai ha ${ }^{-1} \mathrm{~TB}$ application rate, while the $\mathrm{R}$ line increased in height and produced healthy leaves (Figure 1A). Dose-response curve analysis showed that with the use of the commercial product of $\mathrm{TB}$, the $\mathrm{R}$ line $\left(\mathrm{GR}_{50}=5.12 \mathrm{~kg}\right.$ ai ha $\left.{ }^{-1}\right)$ was 6.1-fold more resistant to $\mathrm{TB}$ compared with the $\mathrm{S}$ line $\left(\mathrm{GR}_{50}=0.84 \mathrm{~kg}\right.$ ai ha $\left.{ }^{-1}\right)$ (Figure $\left.1 \mathrm{~B}\right)$. These results were similar to those of a previous study (Fischer et al. 2000), wherein the computed RI of the $\mathrm{R}$ line in comparison to the $\mathrm{S}$ line was 7.8 to $>13.3$-fold.

Results of the laboratory experiment showed that TB had a marked effect on the growth of the $\mathrm{S}$ line even at low doses, while the same doses had a negligible effect on the $\mathrm{R}$ line (Figure $1 \mathrm{C}$ and D). The $S$ line showed stunting and cessation of growth at as low as $1 \mu \mathrm{M}$ TB concentration, while the $\mathrm{R}$ line remained healthy and green at the same herbicide concentration (Figure 1C). Doseresponse curve analysis in MS media revealed that the $\mathrm{R}$ line $\left(\mathrm{GR}_{50}=7.73 \mu \mathrm{M}\right)$ was 14.6 -fold more resistant to TB compared with the $S$ line $\left(\mathrm{GR}_{50}=0.53 \mu \mathrm{M}\right)$ (Figure $1 \mathrm{D}$ ). The result was within close range of the computed RI in the previous study (Fischer et al. 2000) mentioned, thus showing that sensitivity assay in a more controlled setup such as MS media can be applicable for an accurate evaluation of resistance in E. phyllopogon toward TB.

\section{Inheritance of Thiobencarb Resistance in $\mathrm{F}_{6}$ Progenies}

Previous reports showed that the resistances in the $\mathrm{F}_{6}$ progenies perfectly cosegregated across multiple herbicides: ALS inhibitors (BSM and penoxsulam), ACCase inhibitors (diclofop-methyl, tralkoxydim, and pinoxaden), and DXPS inhibitor (clomazone) (Guo et al. 2019; Iwakami et al. 2014, 2019). The cosegregation of resistances among these herbicides is due to a concomitant NTSR mechanism, specifically, a metabolism-based cross-resistance conferred by two cytochrome P450 genes, CYP81A12 and CYP81A21, whose overexpression also cosegregated with the resistances in the $\mathrm{F}_{6}$ progenies (Guo et al. 2019; Iwakami et al. 2014, 2019). To elucidate whether the same NTSR mechanism confers the resistance to $\mathrm{TB}$, the $\mathrm{TB}$ resistance segregation in the $\mathrm{F}_{6}$ progenies was determined and tested to see if it cosegregated with the resistance to ALS inhibitor, BSM. 
(A)

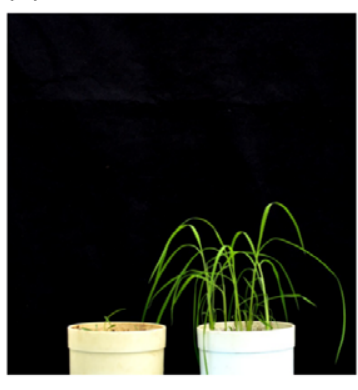

$\mathrm{S}$

$2.5 \mathrm{~kg}$ a.i. ha ${ }^{-1}$

(C)

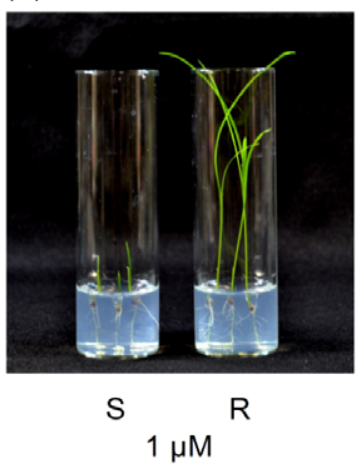

(B)

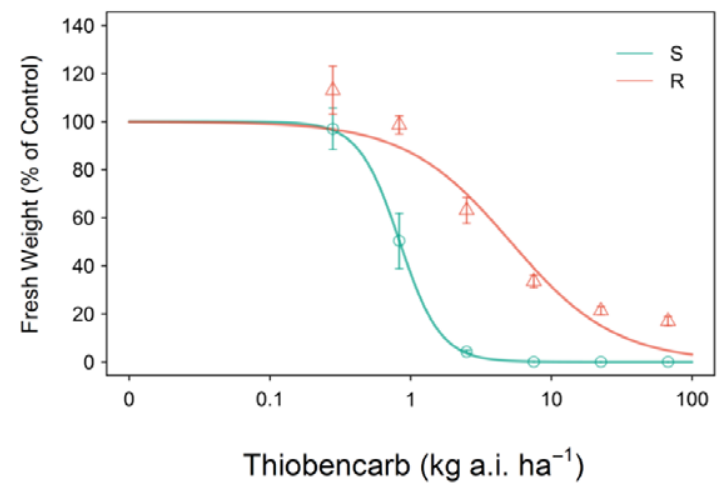

(D)

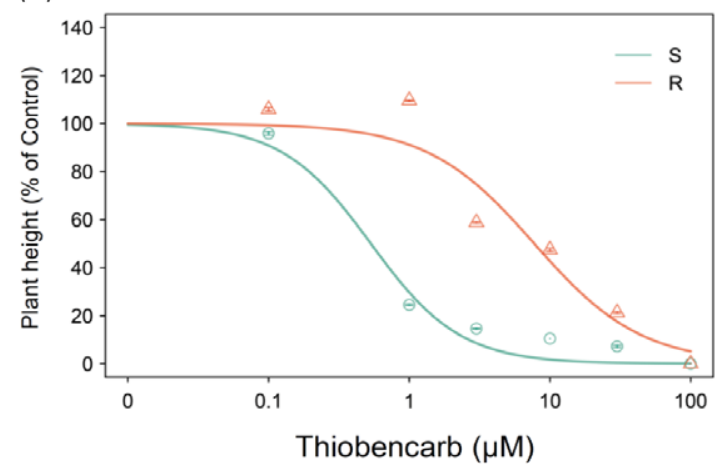

Figure 1. Sensitivity of the parental sensitive (S) line and resistant (R) lines of Echinochloa phyllopogon at $10 \mathrm{~d}$ after treatment of thiobencarb (TB). (A) Sensitivity of parental S and $\mathrm{R}$ lines to the commercial formulation of $\mathrm{TB}\left(2.5 \mathrm{~kg}\right.$ ai ha $\left.{ }^{-1}\right)$. (B) Dose-response curve of parental $\mathrm{S}$ and $\mathrm{R}$ lines to $0,0.09,0.28,0.83,2.5,7.5,22.5$, and $67.5 \mathrm{~kg}$ ai ha ${ }^{-1}$ application rates of TB commercial formulation. (C) Sensitivity of parental S and R lines to $1 \mu \mathrm{M}$ pure active ingredient of TB. (D) Dose-response curve of parental S and R lines to $0,0.1,1,10,30$, and $100 \mu \mathrm{M}$ of TB pure active ingredient. Bars, SE $(n=3)$.

In the cosegregation analysis, we assessed the TB sensitivity of the $\mathrm{F}_{6}$ lines whose sensitivity to BSM and penoxsulam, ACCase inhibitors (diclofop-methyl, tralkoxydim, and pinoxaden), and DXPS inhibitor (clomazone) was previously reported: one resistant line (no. 35), one segregating line (no. 34), and five sensitive lines (nos. 6, 11, 38, 54, and 55) (Guo et al. 2019; Iwakami et al. 2014, 2019). As depicted in Figure 2A, the parental $R$ line survived and grew healthy at $10 \mu \mathrm{M}$ BSM and $1 \mu \mathrm{M}$ TB, while the parental S line almost completely stopped growing and turned brown at $10 \mu \mathrm{M}$ $\mathrm{BSM}$ and had suppressed growth at $1 \mu \mathrm{M} \mathrm{TB}$. As for the sensitivity of the $\mathrm{F}_{6}$ progenies, the results clearly showed different resistance trait segregation between BSM and TB (Figure 2B). For instance, $\mathrm{F}_{6}$ line 34 showed segregating response to BSM but exhibited a fixed sensitive phenotype toward TB (Figure $3 \mathrm{~B}$ ). Moreover, $\mathrm{F}_{6}$ line 35 was resistant to BSM but sensitive to $\mathrm{TB}$, while $\mathrm{F}_{6}$ lines 54 and 55 exhibited an opposite trend (Figure 2B). Meanwhile, $\mathrm{F}_{6}$ lines 6 and 11 were both sensitive to BSM but exhibited intermediate responses to $\mathrm{TB}$, whereas $\mathrm{F}_{6}$ line 38 was sensitive to BSM but showed a segregating phenotype to $\mathrm{TB}$ (Figure $2 \mathrm{~B}$ ). The resistances to BSM and TB segregated independently in the $\mathrm{F}_{6}$ progenies, which provides strong evidence that the mechanism involved in $\mathrm{TB}$ resistance in $\mathrm{R}$ E. phyllopogon is distinct from that of resistance to ALS, ACCase, and DXPS inhibitors. The occurrence of $\mathrm{F}_{6}$ lines with intermediate response to TB may suggest that TB resistance is under the control of multiple loci, although the limited number of subjected seeds per line cannot exclude the possibility that we misannotated the resistant phenotype as intermediate or segregating due to variation of seedling growth rate. Further investigation will be required to clarify this notion.
Sensitivity of Arabidopsis thaliana Expressing CYP81A12/21 to Thiobencarb and Bensulfuron-Methyl

In this study, the non-involvement of CYP81A12 and CYP81A21, the constitutively highly expressed P450s in the $\mathrm{R}$ line, in TB resistance was assessed by sensitivity testing of transgenic A. thaliana expressing the genes. BSM sensitivity of the transgenic lines was also tested as a positive control. Based on the results, the sensitivities of CYP81A12- and CYP81A21expressing lines as compared with WT were not significantly different toward TB (Figure $3 \mathrm{~A}$ and $\mathrm{C}$ ), but the transgenic lines showed a very high level of tolerance toward BSM (Figure 3B and C). Leaf curling and chlorosis were evident in both WT and transgenic lines at as low as $10 \mu \mathrm{M}$ of TB, and complete cessation of growth was observed at $30 \mu \mathrm{M}$ and $100 \mu \mathrm{M}$ concentrations (Figure 3A and C). On the other hand, the transgenic lines were tolerant to even 1,000-fold higher concentration of BSM, while the WT showed significant reduction in rosette diameter at as low as $1 \mathrm{nM}$ concentration and completely stopped growing at 10,100, and 1,000 $\mathrm{nM}$ concentrations (Figure $3 \mathrm{~B}$ and $\mathrm{C}$ ). These results confirm that CYP81A12 and CYP81A21, which confer resistance to BSM and other herbicides (Guo et al. 2019; Iwakami et al. 2014, 2019), are not the genes conferring $\mathrm{TB}$ resistance in $\mathrm{R}$ E. phyllopogon. This is consistent with our recent findings that none among the nine putative functional CYP81As of E. phyllopogon conferred the high level of TB tolerance (RI of $\geq 3.0$ ) when the genes were ectopically expressed in A. thaliana (Dimaano et al. 2020). These results suggest that aside from the CYP81As that were found to be involved in 
(A)

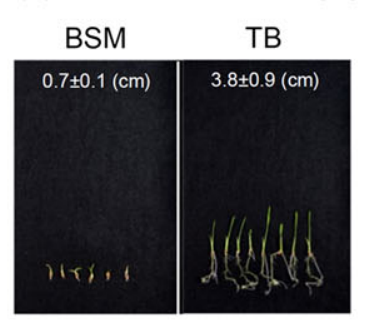

S
Parental lines

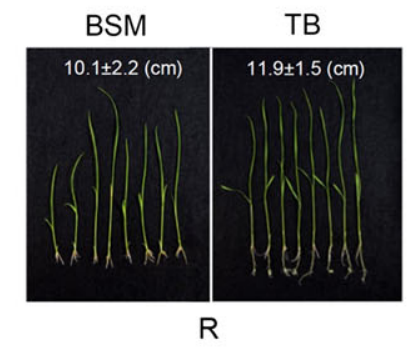

(B)
BSM

\#34
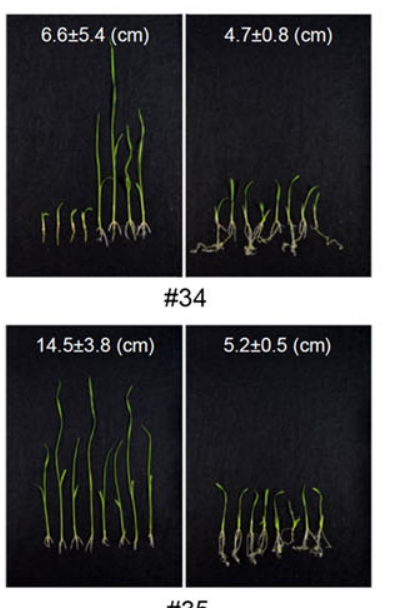

\#35
TB

\section{.}

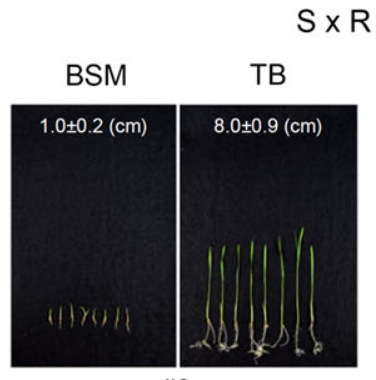

\#6

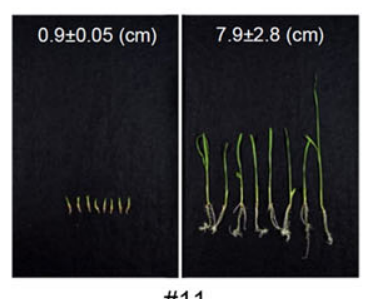

BSM

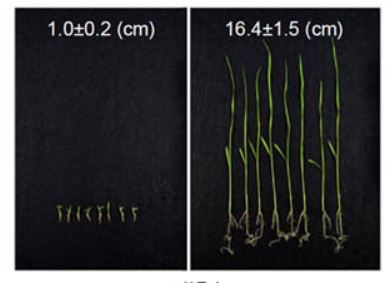

\#54

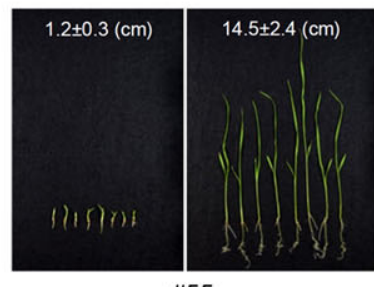

BSM

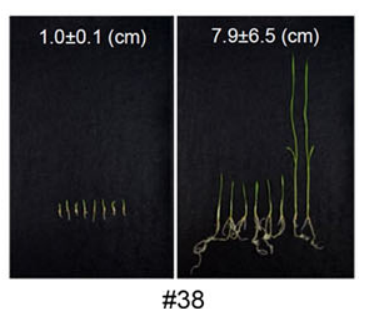

I Bar $=5 \mathrm{~cm}$

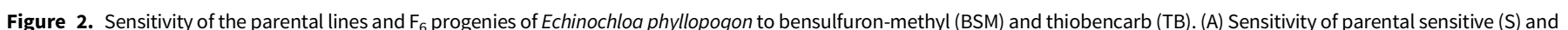

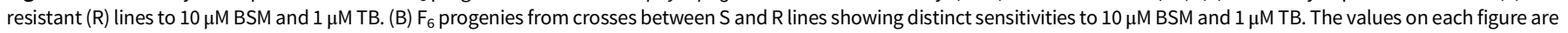

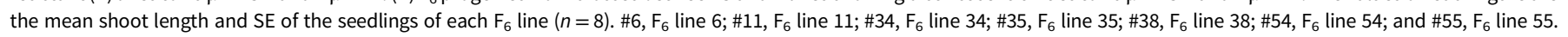

metabolism-based cross-resistance in E. phyllopogon, there might be other resistance-conferring genes that may have been selected for by the many years of TB application in California rice fields.

\section{Probable Mechanism(s) of Thiobencarb Resistance in Echinochloa phyllopogon}

The repeated use of few available grass herbicides (thiobencarb, molinate, fenoxaprop- $P$-ethyl, etc.) in predominantly monoculture rice fields in California has resulted in the selection for genes conferring resistance to multiple MOAs in E. phyllopogon (Fischer et al. 2000). Resistance to multiple herbicides including TB was also reported in other related species such as E. crus-galli (Heap 1997) and early watergrass [Echinochloa oryzoides (Ard.) Fritsch] (Fischer et al. 2000). Similar to E. phyllopogon, it has not been determined whether the mechanism of resistance to multiple herbicides in E. crus-galli and E. oryzoides is caused by a single NTSR mechanism (cross-resistance) or by multiple NTSR mechanisms (multiple resistance). Although a TSR-based multiple resistance was recently reported for several ACCase inhibitors in E. crus-galli (Fang et al. 2020), TSR-based TB resistance in these $\mathrm{R}$ Echinochloa spp. populations is less likely to occur. This is because VLCFAEs inhibited by TB are composed of a multienzyme complex, which would require highly improbable concomitant mutations in several different targets before the resistance could occur (Busi 2014; Tanetani et al. 2013; Trenkamp et al.
2004). Thus, the TB resistance observed in R populations of E. phyllopogon, E. oryzoides, and E. crus-galli is highly likely to be due to an NTSR-based mechanism. The inheritance study and transgenic plant assay we performed strongly hinted the coexistence of another mechanism involved in TB resistance in $\mathrm{R}$ E. phyllopogon. The next important step for this research is to identify the key gene(s) endowing TB resistance in the $\mathrm{R}$ line.

TB metabolism in Echinochloa spp. is similar to that of rice, but the detoxification activity in rice is higher (Usui 2001). Accordingly, TB is metabolically detoxified via monooxygenation/hydroxylation reactions, for example, de-ethylation and hydroxylation of a phenyl ring at the 2-position (Usui 2001). As these are typical reactions mediated by plant P450s (Dimaano and Iwakami 2021), it would be probable that an enhanced activity of $\mathrm{P} 450$ (s) underlies TB resistance in R E. phyllopogon. Induced TB-metabolizing microsomal activity in the $\mathrm{R}$ line (Yun et al. 2005) also supports this notion. Meanwhile, the study does not exclude the possible involvement of other mechanisms, such as detoxification by other endogenous enzymes, reduced uptake and translocation, or protection against oxidative damages, among others. All possible NSTR-based mechanisms conferring TB resistance merit careful investigation.

Taking advantage of the molecular identification of the responsible genes and the development of crossed progenies, we demonstrated that the "single mechanism" extending resistance to a wide range of herbicides fails to endow resistance to TB. Our findings 
(A)

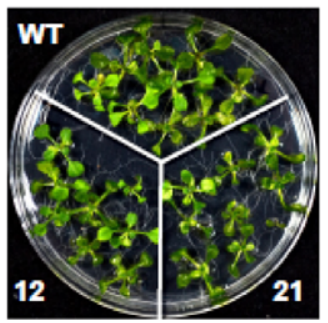

0

(B)

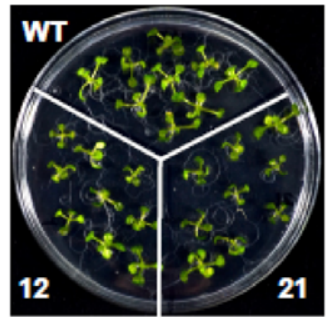

0

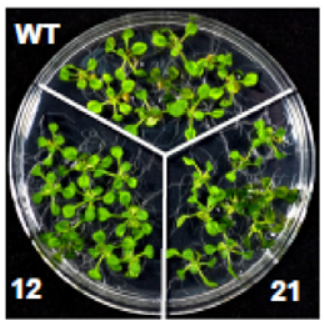

3

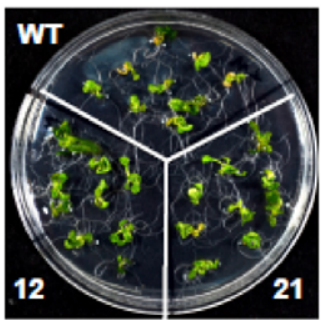

10

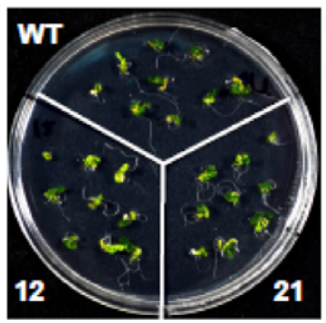

30

Thiobencarb $(\mu \mathrm{M})$

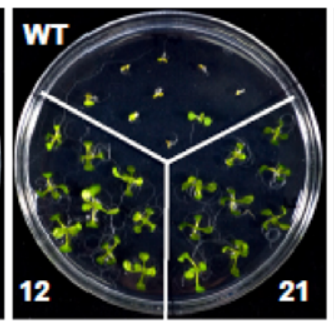

1

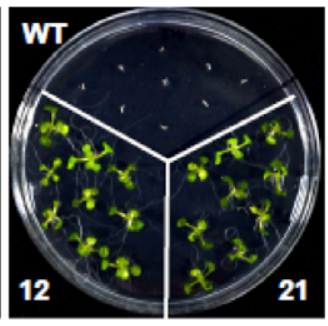

10

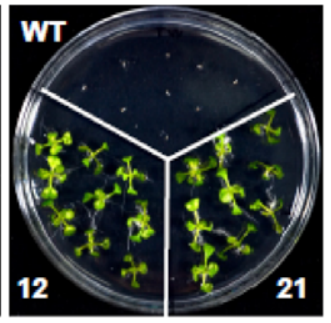

100

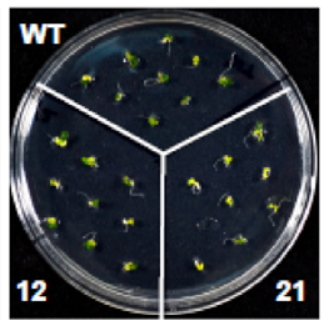

100

Bensulfuron-methyl (nM)

(C)
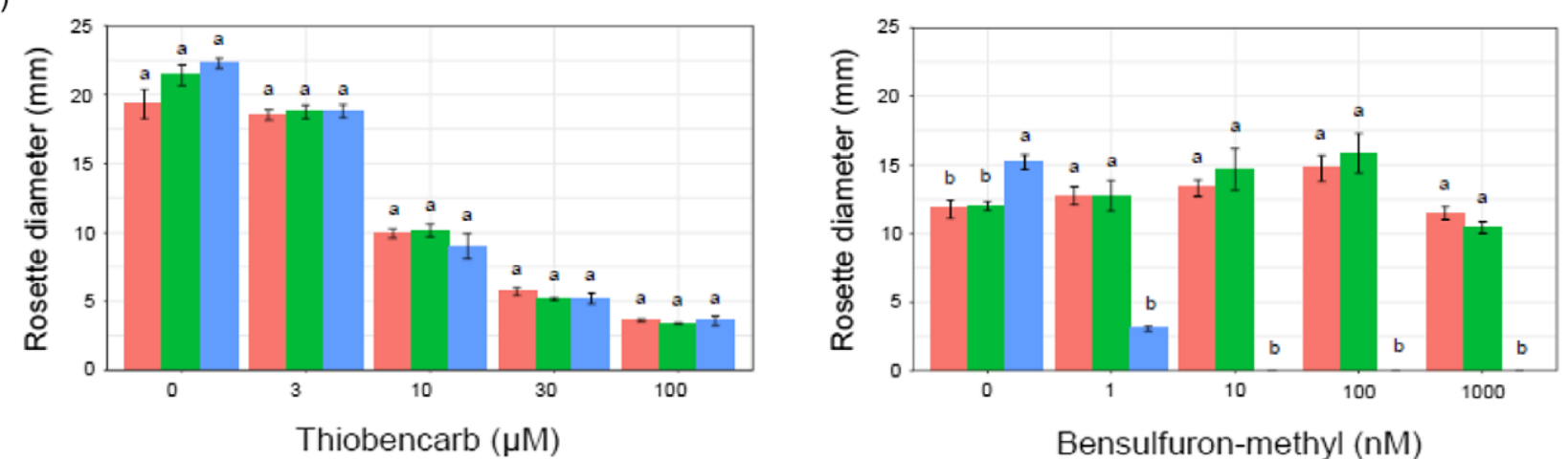

Bensulfuron-methyl (nM)

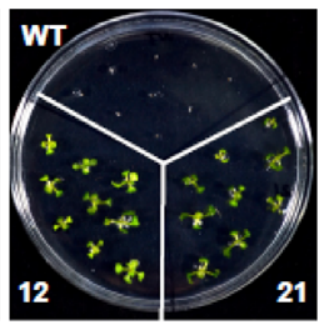

1000

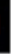


Délye C (2013) Unravelling the genetic bases of non-target-site-based resistance (NTSR) to herbicides: a major challenge for weed science in the forthcoming decade. Pest Manag Sci 69:176-187

Délye C, Duhoux A, Pernin F, Riggins CW, Tranel PJ (2015) Molecular mechanisms of herbicide resistance. Weed Sci 63:91-115

Dimaano NG, Iwakami S (2021) Cytochrome P450-mediated herbicide metabolism in plants: current understanding and prospects. Pest Manag Sci 77:22-32

Dimaano NG, Yamaguchi T, Fukunishi K, Tominaga T, Iwakami S (2020) Functional characterization of cytochrome P450 CYP81A subfamily to disclose the pattern of cross-resistance in Echinochloa phyllopogon. Plant Mol Biol 102:403-416

Fang J, He Z, Liu T, Li J, Dong L (2020) A novel mutation Asp-2078-Glu in ACCase confers resistance to ACCase herbicides in barnyardgrass (Echinochloa crus-galli). Pestic Biochem Physiol 168:article 104634

Fang J, Liu T, Zhang Y, Li J, Dong L (2019) Target site-based penoxsulam resistance in barnyardgrass (Echinochloa crus-galli) from China. Weed Sci 67:281-287

Feng Y, Gao Y, Zhang Y, Dong L, Li J (2016) Mechanisms of resistance to pyroxsulam and ACCase inhibitors in Japanese foxtail (Alopecurus japonicus). Weed Sci 64:695-704

Fischer AJ, Ateh CM, Bayer DE, Hill JE (2000) Herbicide-resistant Echinochloa oryzoides and E. phyllopogon in California Oryza sativa fields. Weed Sci 48:225-230

Gaines TA, Duke SO, Morran S, Rigon CA, Tranel PJ, Küpper A, Dayan FE (2020) Mechanisms of evolved herbicide resistance. J Biol Chem 295:10307-10330

Guo F, Iwakami S, Yamaguchi T, Uchino A, Sunohara Y, Matsumoto H (2019) Role of CYP81A cytochrome P450s in clomazone metabolism in Echinochloa phyllopogon. Plant Sci 283:321-328

Hall L M, Holtum JAM, Powles SB (1994) Mechanisms responsible for cross resistance and multiple resistance. Pages 243-261 in Powles SB, Holtum JAM, eds. Herbicide Resistance in Plants: Biology and Biochemistry. Boca Raton, FL: Lewis Publishers

Han H, Yu Q, Beffa R, Gonzalez S, Maiwald F, Wang J, Powles S (2021) Cytochrome P450 CYP81A10v7 in Lolium rigidum confers metabolic resistance to herbicides across at least five modes of action. Plant J 105:79-92

Heap I (1997) The occurrence of herbicide-resistant weeds worldwide. Pestic Sci 51:235-243

Hill JE, Le Strange ML, Bayer DE, Williams JF (1985) Integrated weed management in California. Pages 100-104 in Proceedings of the Western Society of Weed Science (USA). Phoenix, AZ: Western Society of Weed Science

Iwakami S, Endo M, Saika H, Okuno J, Nakamura N, Yokoyama M, Watanabe H, Toki S, Uchino A, Inamura T (2014) Cytochrome P450 CYP81A12 and CYP81A21 are associated with resistance to two acetolactate synthase inhibitors in Echinochloa phyllopogon. Plant Physiol 165:618-629

Iwakami S, Kamidate Y, Yamaguchi T, Ishizaka M, Endo Masaki, Suda H, Nagai K, Sunohara Y, Toki S, Uchino A, Tominaga T, Matsumoto H (2019) CYP81A P450s are involved in concomitant cross-resistance to acetolactate synthase and acetyl-CoA carboxylase herbicides in Echinochloa phyllopogon. New Phytol 221:2112-2122

Jasieniuk M, Brûlé-Babel AL, Morrison IN (1996) The evolution and genetics of herbicide resistance in weeds. Weed Sci 44:176-193
Osuna MD, Vidotto F, Fischer AJ, Bayer DE, De Prado R, Ferrero A (2002) Cross-resistance to bispyribac-sodium and bensulfuron-methyl in Echinochloa phyllopogon and Cyperus difformis. Pestic Biochem Physiol 73:9-17

Powles S, Yu Q (2010) Evolution in action: plants resistant to herbicides. Annu Rev Plant Biol 61:317-347

Rasband WS (1997) ImageJ. Bethesda, MD: U.S. National Institutes of Health

R Core Team (2018) R: A Language and Environment for Statistical Computing. Vienna, Austria: R Foundation for Statistical Computing

Ritz C, Baty F, Streibig JC, Gerhard D (2015) Dose-response analysis using R. PLoS ONE 10(12):e0146021

Roberts TR, Hutson DH, Lee PW, Nicholls PH, Plimmer JR, Roberts MC, Croucher L (1998) Metabolic Pathways of Agrochemicals. Part 1: Herbicides and Plant Growth Regulators. Cambridge, UK: Royal Society of Chemistry. Pp 610-617

Ruiz-Santaella JP, De Prado R, Wagner J, Fischer A, Gerhards R (2006) Resistance mechanisms to cyhalofop-butyl in a biotype of Echinochloa phyllopogon (Stapf) Koss. from California. J Plant Dis Protect XX:95-100

Shergill LS, Bish MD, Jugulam M, Bradley KW (2018) Molecular and physiological characterization of six-way resistance in an Amaranthus tuberculatus var. rudis biotype from Missouri. Pest Manag Sci 74:2688-2698

Tanetani Y, Kaku K, Ikeda M, Shimizu T (2013) Action mechanism of a herbicide, thiobencarb. J Pestic Sci 38:39-43

Trenkamp S, Martin W, Tietjen K (2004) Specific and differential inhibition of very long-chain fatty acid elongases from Arabidopsis thaliana by different herbicides. Proc Natl Acad Sci USA 101:11903-11908

Tsuji R, Fischer AJ, Yoshino M, Roel A, Hill JE, Yamasue Y (2003) Herbicideresistant late watergrass (Echinochloa phyllopogon): similarity in morphological and amplified fragment length polymorphism traits. Weed Sci 51:740-747

Usui K (2001) Metabolism and selectivity of rice herbicides in plants. Weed Biol Manag 1:137-146

Yamasue Y (2001) Strategy of Echinochloa oryzicola Vasing. for survival in flooded rice. Weed Biol Manag 1:28-36

Yasuor H, Milan M, Eckert JW, Fischer AJ (2012) Quinclorac resistance: a concerted hormonal and enzymatic effort in Echinochloa phyllopogon. Pest Manag Sci 68:108-115

Yasuor H, Osuna MD, Ortiz A, Saldain NE, Eckert JW, Fischer AJ (2009) Mechanism of resistance to penoxsulam in late watergrass [Echinochloa phyllopogon (Stapf) Koss.]. J Agric Food Chem 57:3653-3660

Yasuor H, Zou W, Tolstikov VV, Tjeerdema RS, Fischer AJ (2010) Differential oxidative metabolism and 5-ketoclomazone accumulation are involved in Echinochloa phyllopogon resistance to clomazone. Plant Physiol 153: 319-326

Yu Q, Powles S (2014) Metabolism-based herbicide resistance and cross-resistance in crop weeds: a threat to herbicide sustainability and global crop production. Plant Physiol 166:1106-1118

Yuan JS, Tranel PJ, Stewart CN Jr (2007) Non-target-site herbicide resistance: a family business. Trends Plant Sci 12:6-13

Yun M-S, Yogo Y, Miura R, Yamasue Y, Fischer AJ (2005) Cytochrome-P450 monooxygenase activity in herbicide-resistant and -susceptible late watergrass (Echinochloa phyllopogon). Pestic Biochem Physiol 83:107-114 